\title{
Microbes Identified from Some Caves of Bastar, Chattisgarh and their
} Biocalcifying Abilities

\author{
Sushmitha Baskar', Swati Chalia², Ramanathan \\ Baskar $^{2 *}$ \\ ${ }^{1}$ Environmental Studies, School of Interdisciplinary and \\ Transdisciplinary Studies (SOITS), Indira Gandhi National \\ Open University (IGNOU), New Delhi, 110068, India \\ ${ }^{2}$ Department of Environmental Science and Engineering, Guru \\ Jambheshwar University of Science and Technology, Hisar, \\ Haryana, 125001, India.
}

Study Area: in and around Kanger Valley National Park, Bastar, Chhattisgarh, India Coordination: $18^{\circ} 45^{\prime} \mathrm{N} 82^{\circ} 10^{\prime} \mathrm{E}$

Key words: Kotumsar, Geomicrobiology, Speleothems, Biomineralization, Kanger Valley National Park.

\section{Introduction:}

Cave environments host diverse microorganisms and they are sites of active mineral precipitation. The subject matter of cave geomicrobiology deals with the interactions of microbes with minerals present in caves. Microbes and their metabolisms are important drivers of biogeochemical processes. Several microorganisms have been identified in caves such as- Actinobacteria sp., Leptothrix sp., Myxobacteria sp., Pseudomonas sp., Bacillus sp. etc. (Cañaveras et al., 2001; Northup et al., 2011; Baskar et al., 2012, 2016) of which some are useful in biorestoration applications.

Researchers have demonstrated the ability of microbes isolated from the caves and marine environments to form biominerals under controlled conditions (Danielli \& Edington, 1983; Rivadeneyra et al., 1993; Baskar et al., 2006, 2014, 2016).

Though the Indian sub-continent hosts a number of caves, only a handful reports have focussed on the geomicrobiology of caves. Paleoclimatological studies, biospeleology and some attempts on cave microbiology have been made in some caves of Chhattisgarh (Biswas, 1992; 2010; Sinha et al., 2011; Yadava et al., 2007; Biswas \& Shrotriya, 2011; Rajput et al., 2012a,b, 2014; Rajput \& Biswas, 2012; Biswas et al., 2011; 2015). The present study reports on the geomicrobiological studies of some caves from Chhattisgarh. The main objective of the study is to understand the metabolic capability of the isolated microbes from these caves in precipitating calcite in vitro.

Rani Cave: the cave ( $\sim 50 \mathrm{~m}$ in length) is situated in Chitapur village of block Tokapal, district Bastar, Chhattisgarh. In vitro culture experiments, using three bacterial strains $\mathrm{CSJC}_{1}, \mathrm{CSJC}_{2}, \mathrm{CSJC}_{3}$ isolated from speleothems from Rani Cave, were examined for their biomineralization potential. The speleothems showed high microbial cell numbers on nutrient agar $\left(9 \times 10^{4}\right.$ CFU/g). The BLASTn sequence search of $16 \mathrm{~S}$ rRNA sequences with the NCBI database yielded similarity scores of $=99 \%$ with the respective organisms and the strains were identified as CSJC1- Bacillus sp., CSJC2 Cupriavidus sp., $\mathrm{CSJC}_{3}$ - Bacillus sp. All the strains precipitated calcite in vitro (Fig.-1, Table-1).

Kotumsar Cave: this cave is situated in the Kanger Valley National Park in Bastar district, Chhattisgarh and is the major tourist attraction point of the state. The cave is reported to be one of the biologically well-explored caves in India. It has a number of highly endemic species on the verge of extinction (Biswas, 2010). These speleothems showed high microbial cell enumerations on $\mathrm{B} 4$ agar (3.4 X $\left.10^{5} \mathrm{CFU} / \mathrm{g}\right)$ followed by sulphite agar $\left(7.2 \times 10^{2} \mathrm{CFU} / \mathrm{g}\right)$. The BLASTn sequence search of $16 \mathrm{~S}$ rRNA sequences with the NCBI database to establish the identity of $\mathrm{S}_{14}$ strain yielded similarity scores of $=99 \%$ with the respective organisms and the strain was identified as Rhodococcus sp. (Table-1). Culture experiments indicated that the rate of precipitation was controlled by factors like $\mathrm{pH}$, temperature and bacterial growth. Rhodococcus sp. S14 strain induced the formation of calcite in vitro. The biominerals produced were calcified spherulites with pores. It had the appearance of coccoliths.

Jhumar Cave: it is situated near the Pedawada village of block Darbha, district Bastar, Chhattisgarh. It is located in the periphery of Kanger Valley National Park. These speleothems showed high microbial cell enumerations on Iron agar $\left(9.0 \times 10^{4} \mathrm{CFU} / \mathrm{g}\right)$ followed by sulphite agar $(4.0 \times$ $10^{3} \mathrm{CFU} / \mathrm{g}$ ). Three strains $\mathrm{S}_{1}, \mathrm{~S}_{2}$ and $\mathrm{S}_{3}$ from JMST1, JMST2 and $\mathrm{JMST}_{3}$ samples were tested under controlled conditions of temperatures $\left(18-25^{\circ} \mathrm{C}\right)$ for precipitation of crystals. During calcite precipitation, the $\mathrm{pH}$ of medium increased. The strains precipitated calcite of $0.55 \mathrm{~g}, 0.43 \mathrm{~g}$ and $0.47 \mathrm{~g}$ respectively in the 30 days experiment period. The strains were identified were Achromobacter insolitus, Bacillus subtilis, and Bacillus flexus (Table-1, Fig.-1). 
Table 1: Microbial diversity and biocalcifying abilities of strains identified in caves in Chhattisgarh

\begin{tabular}{|c|c|c|c|c|c|c|}
\hline $\begin{array}{l}\text { Name of } \\
\text { cave }\end{array}$ & $\begin{array}{l}\text { Type of } \\
\text { deposit }\end{array}$ & $\begin{array}{l}\text { Bacterial count } \\
\mathrm{cfu} / \mathrm{g}\end{array}$ & $\begin{array}{l}\text { Identif ied species/ } \\
\text { phylotype }\end{array}$ & $\begin{array}{l}\text { Identif ication } \\
\text { technique }\end{array}$ & $\begin{array}{l}\text { Biocalcification } \\
\text { ability }\end{array}$ & $\begin{array}{l}\text { Biomineral } \\
\text { formed }\end{array}$ \\
\hline Rani & Cave wall & Nutrient agar $9 \times 10^{4}$ & Cupriavidus sp., Bacillus sp. & DNA sequencing & Yes & Calcite \\
\hline Kotumsar & Cave wall & $\begin{array}{l}\text { B4 agar } 3.4 \times 10^{5} \\
\text { Sulphite agar } 7.2 \times 10^{2}\end{array}$ & $\begin{array}{l}\text { Rhodococcus sp., } \\
\text { Bacillus sp., Micrococcus sp., } \\
\text { Staphylococcus sp., }\end{array}$ & DNA sequencing & Yes & Calcite \\
\hline Jhumar & Stalactite & $\begin{array}{l}\text { Iron agar } 9.0 \times 10^{4} \\
\text { Sulphite agar } 4.0 \times 10^{3}\end{array}$ & $\begin{array}{l}\text { Achromobacter insolitus., } \\
\text { Bacillus subtilis., Bacillus flexus }\end{array}$ & DNA sequencing & Yes & Calcite \\
\hline
\end{tabular}

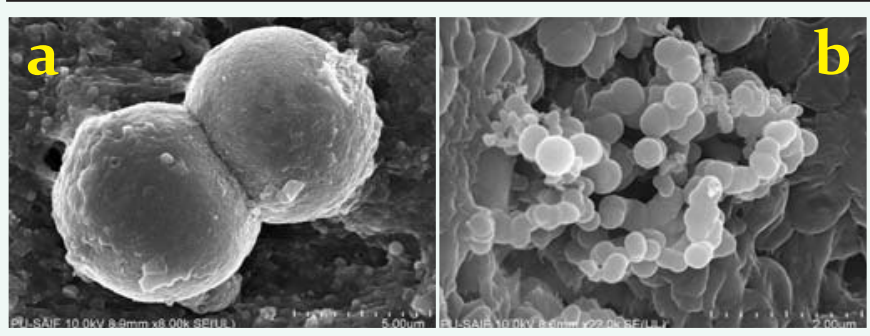

Figure-1: (a) Dumbbell shaped $\mathrm{CaCO}_{3}$ precipitated by Cupriavidus sp. isolated from Rani and Jhumar cave speleothems (b) Calcite precipitated by Achromobacter insolitus isolated from Jhumar cave.

\section{Conclusion:}

This note summarizes the studies performed on some caves from Chattisgarh to throw light on microbe-mineral interactions. In this study, the isolated microbes through their metabolic activities have resulted in biocalcification. It can help in understanding biomineralization in caves. In vitro studies suggest that these isolated microbes help in biomineralization through biologically induced mechanisms. It establishes that bacterial metabolism does influence the calcite precipitation process.

Acknowledgements:

Authors are thankful to Prof. Minakshi Prasad, Dept. of Animal Biotechnology, College of Veterinary Sciences, LLR University of Animal and Veterinary Sciences, Hisar; Panjab University, Chandigarh; geneOmbio Technologies, Pune for analyses and research facilities. Dr. Jayant Biswas is thanked for help in field work at Chattisgarh. Swati Chalia thanks UGC-BSR for fellowship.

\section{References:}

Baskar, S., Baskar, R., Mauclaire, L. \& McKenzie, J.A. (2006): Microbially induced calcite precipitation by culture experiments possible origin for stalactites in Sahastradhara, Dehradun, India. Curr. Sci., 90:58-64.

Baskar, S., Baskar, R., Thorseth, I.H., Ovreas, L. \& Pedersen, R.B. (2012): Microbial iron precipitation associated with a neutrophilic spring of Borra caves, Vishakapatanam, India. Astrobiol.J., 12(4):327-346.

Baskar, S., Baskar, R. \& Routh, J. (2014): Speleothems from Sahastradhara Caves in Siwalik Himalaya, India: Possible Biogenic Inputs. Geomicrobiol.J., 31:664-681.

Baskar, S., Routh, J., Baskar, R., Kumar, A., Miettinen, H. \& Itavaara, M. (2016): Evidences For Microbial Precipitation of Calcite in Speleothems from Krem Syndai in Jaintia Hills, Meghalaya, India. Geomicrobiol. J.33(10):1-28.

Biswas, J. (1992): Kotumsar Cave ecosystem: an interaction between geophysical, chemical and biological characteristics. NSS Bull., 139:7-10.

Biswas, J. (2010): Kotumsar cave biodiversity: a view of cavernicoles and their troglophili ctraits. Biodivers. Conserv., 19:279-285.

Biswas, J. \& Shrotriya, S. (2011): Dandak: the mammalian dominated cave ecosystem of India. Int.J. Subter. Biol., 40:1-7.

Biswas, J, Shrotriya, S., Rajput, Y. \& Sasmal, S. (2011): Impacts of Ecotourism on Bat Habitats in Caves of Kanger Valley National Park, India. Res. J. Environ. Sci., 5(9):752-762.

Biswas, J., Neral, A. \& Rajput, Y. (2015): Subterranean Microhabitat Dependent Intra Versus Extracellular Enzyme Secretion Capabilities of Deinococcus radiodurans. Amb. Sci., 2:44-50.

Cañaveras, J.C. Cuezva, S., S'anchez-Moral, S., Lario, J., Laiz, L., Gonz'alez, J.M. \& Saiz-Jim'enez, C. (2006): On the origin of fiber calcite crystals in moonmilk deposits Naturwissenschaften, 93:27-32.

Danielli, H.M.C. \& Edington, M.A. (1983): Bacterial calcification in limestone caves. Geomicrobiol. J., 3:1-16.

Northup, DE. Melim, LA. Spilde, MN. Hathaway, JJM. Garcia, MG. Moya, M. Stone, FD. Boston, PJ. Dapkevicius, MLNE, and Riquelme, C. (2011), "Lava Cave microbial communities within mats and secondary mineral deposits: Implications for life detection on other planets", Astrobiology 12(7):601618.

Rajput, Y. \& Biswas, J. (2012): Subterranean depth dependent protein constitutions of the Micrococcus sp., isolated from the Kotumsar cave, India. Asian J. Biochem., 7(2):90-97.

Rajput, Y., Biswas, J. \& Rai, V. (2012): Potentiality test in antimicrobial activity and antibiotic sensitivity of Subterranean Streptomyces strains; isolated from Kotumsar cave of India. Int. J. Biol. Chem., 6(2):53-6o.

Rajput, Y., Rai, V. \& Biswas, J. (2012): Screening of Bacterial isolates from various microhabitat sediments of Kotumsar cave: a cogitation on their respective benefits and expected threats for complete biosphere and tourists. Res. J. Environ. Toxicol., 6(1):13-24.

Rajput, Y., Neral, A. \& Biswas, J. (2014): Subterranean depth dependent the modulation of endo and exoenzyme secretion in Streptomyces prasinosporus: a common soil actinomycete of India. J. Pure App. Microbiol., 8o(6):4601-46o8

Rivadeneyra, MA. Delgado, R. Delgado, G. Del Moral, A. Ferrer, MR. and Ramos-Cormenza, A. (1993), "Precipitation of carbonate by Bacillus sp. isolated from saline soils", Geomicrobiol J 11:175184.

Sinha, A., Berkelhammer, M., Stott, L., Mudelsee, M., Cheng, H. \& Biswas, J. (2011): The leading mode of Indian Summer Monsoon precipitation variability during the last millennium. Geophy. Res. Lett., 38:1-5.

Yadava, M.G., Sarswat, K.S. \& Ramesh, R. (2007): Evidences of early human occupation in the limestone Caves of Bastar, Chattisgarh. Curr. Sci., 92(6): 820-823. 